\title{
Androgen Receptor Immunoreactivity in the Male and Female Syrian Hamster Brain
}

\author{
R. I. Wood, ${ }^{\star}$ S. W. Newman \\ Department of Anatomy and Cell Biology, University of Michigan, Ann Arbor, Michigan 48109-0616
}

Received 6 July 1998; accepted 14 December 1998

\begin{abstract}
To investigate potential mechanisms for sex differences in the physiologic response to androgens, the present study compared the hormonal regulation of intracellular androgen receptor partitioning and the distribution of androgen receptor immunoreactivity in select brain regions from male and female hamsters. Androgen receptors were visualized on coronal brain sections. Two weeks after castration, androgen receptor immunoreactivity filled the neuronal nuclei and cytoplasm in males and females. In gonad-intact males and females, androgen receptor immunoreactivity was limited to the cell nucleus. Whereas exogenous dihydrotestosterone prevented cytoplasmic immunoreactivity, estrogen at physiologic levels did not. These results suggest that nuclear androgen receptor immunoreactivity in gonad-intact females is maintained by endogenous androgens, and that androgens have the potential to influence neuronal activity in either sex. However, sex differences in the number and staining intensity of androgen-re-
\end{abstract}

Steroid hormones produced in the gonads influence behavior and neuroendocrine function via binding to specific receptors in the brain. Although the principle steroid products of the gonads are different in males and females (androgens from the testes, estrogens and progesterone from the ovaries), both sexes can respond to the heterologous steroids. Hence, estrogens suppress the secretion of luteinizing hormone and

* Current address: Department of Obstetrics and Gynecology, Yale University School of Medicine, 333 Cedar St., Box 208063, New Haven, CT 06520-8063

Correspondence to: R. I. Wood at Yale University

Contract grant sponsor: NIH; contract grant numbers: NS20629, HD-07514

(C) 1999 John Wiley \& Sons, Inc. CCC 0022-3034/99/030359-12 sponsive neurons were apparent in select brain regions. In the ventral premammillary nucleus, ventromedial nucleus of the hypothalamus, and medial amygdaloid nucleus, androgen receptor staining was similar in gonadectomized males and females. In the lateral septum, posteromedial bed nucleus of the stria terminalis (BNSTpm), and medial preoptic nucleus, the number of androgen receptor-immunoreactive neurons was significantly lower in females $(p<.05)$. Moreover, the integrated optical density/cell in BNSTpm was significantly less in females $(1.28 \pm 0.3$ units $)$ than in males $(2.21$ \pm 0.2 units; $p<.05)$. These sex differences in the number and staining intensity of androgen-responsive neurons may contribute to sex differences in the behavioral and neuroendocrine responses to androgens. ๑ 1999 John Wiley \& Sons, Inc. J Neurobiol 39: 359-370, 1999

Keywords: androgen receptor; brain; sex differences; hamster; immunohistochemistry

stimulate mounting behavior in male hamsters (DeBold and Clemens, 1978; Ellis and Turek, 1980; Powers et al., 1985), and estrogen receptors are found in the male brain (see Simerly, 1995). In a similar manner, exogenous androgens facilitate mounting and inhibit gonadotropin secretion in female hamsters (DeBold and Clemens, 1978; Yellon et al., 1989). Although early investigators failed to locate receptors for androgen in the female rat brain (Gustafsson et al., 1976), subsequent studies have since identified androgen receptors in brains from females as well as males. However, female hamsters are quantitatively less responsive than males to the stimulatory and inhibitory actions of androgens on neuroendocrine function and sexual behavior (DeBold and Clemens, 1978; Yellon 

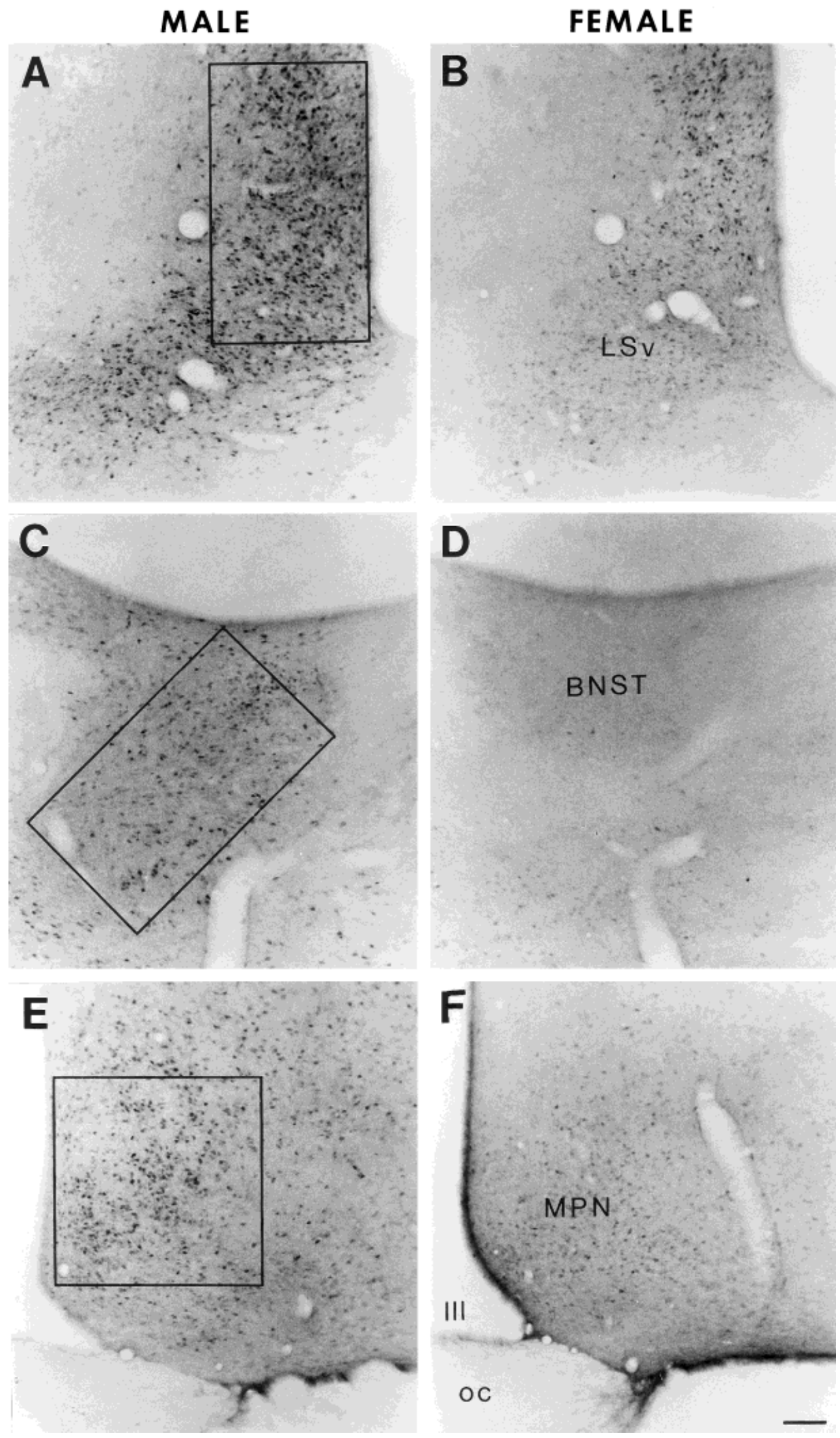
et al., 1989). This leads to the hypothesis that the function, location, or number of androgen receptors in female brain may be less than that of the male.

To investigate potential anatomical bases for the sex differences in the behavioral and neuroendocrine responses to androgen, the present study compared the amount of androgen receptor immunoreactivity in selected brain areas and the hormonal regulation of intracellular androgen receptor partitioning from male and female hamsters. Androgen receptor immunoreactivity is visible in both the neuronal cell nucleus and cytoplasm after castration (Wood and Newman, 1993a; Freeman et al., 1995; Kashon et al., 1995). Furthermore, cytoplasmic androgen receptor immunoreactivity is reduced (Wood and Newman, 1993a; Freeman et al., 1995; Kashon et al., 1995) and nuclear staining is increased by exogenous androgen (Menard and Harlan, 1993; Wood and Newman, 1993a; Clancy et al., 1994; Zhou et al., 1994; Freeman et al., 1995; Kashon et al., 1995), suggesting that these cytoplasmic receptors are capable of nuclear translocation in the presence of ligand. Thus, changes in intracellular androgen receptor partitioning in response to a hormonal challenge may be an index of receptor binding.

\section{MATERIALS AND METHODS}

\section{General Methods}

Adult hamsters (Mesocricetus auratus) weighing between 90 and $110 \mathrm{~g}$ were purchased from Charles River Laboratories. They were housed in same-sex groups of 3-6/cage under a long-day photoperiod (14:14 h light/day cycle). Food and water were available at all times.

\section{Perfusion and Immunocytochemistry}

Hamsters were deeply anesthetized with sodium pentobarbital $(130 \mathrm{mg} / \mathrm{kg})$ and perfused through the aorta with 150 $\mathrm{mL}$ of $0.1 \mathrm{M}$ sodium phosphate-buffered saline containing $0.1 \%$ sodium nitrite for vasodilation, followed by $250 \mathrm{~mL}$ of $0.1 \mathrm{M}$ sodium phosphate buffer (PB) containing $4 \%$ paraformaldehyde. Brains were removed and postfixed in the perfusion fixative for $1 \mathrm{~h}$ at room temperature and then cryoprotected overnight in PB with $20 \%$ sucrose at $4^{\circ} \mathrm{C}$. Forty-micrometer coronal brain sections were cut on a freezing microtome and collected into PB with $0.01 \%$ so- dium azide as a preservative. Sections were stored at $4{ }^{\circ} \mathrm{C}$ until processed for immunocytochemistry.

Every fourth section was immunostained for androgen receptors. To demonstrate androgen receptor immunoreactivity, a polyclonal rabbit antibody was used. This antibody (PG-21: $0.5 \mu \mathrm{g} / \mathrm{mL}$ in PB with $0.3 \%$ Triton $\mathrm{X}-100$ ) is directed against a synthetic peptide corresponding to the first 21 amino acids of the rat androgen receptor (gift of Dr. Gail S. Prins, University of Illinois-Chicago). Details of the isolation and characterization of this antibody are described in Prins et al. (1991). PG-21 has been validated previously for the study of androgen receptors in the male Syrian hamster brain (Wood and Newman, 1993a,b). Immunostaining of androgen receptor-containing neurons followed the protocol reported previously (Wood and Newman, 1993a). Briefly, free-floating sections were washed three times for $5 \mathrm{~min}$ in $\mathrm{PB}$ and incubated in primary antiserum with $4 \%$ normal donkey serum for $48 \mathrm{~h}$ at $4^{\circ} \mathrm{C}$. The sections were washed and transferred to a biotinylated secondary antibody [donkey anti-rabbit immunoglobulin g ( $\mathrm{IgG}$ ), 1:200; Jackson Immunoresearch Labs] for $1 \mathrm{~h}$ at room temperature. Sections were again rinsed, then incubated for $1 \mathrm{~h}$ in the avidin-biotin horseradish peroxidase (HRP) complex (Vectastain ABC Elite kit; Vector Laboratories). HRP was visualized using nickel chloride-enhanced 3,3'-diaminobenzidine (DAB) as the chromagen. All sections were exposed to DAB for $1 \mathrm{~h}$. This lengthy incubation was necessary to visualize androgen receptor immunoreactivity in the neuronal cell nucleus and cytoplasm from gonadectomized males and females, although nuclear staining in brains of androgen-treated hamsters was evident within 5 min of DAB exposure (Wood and Newman, 1993a). Cytoplasmic immunoreactivity was not observed in hamsters with androgen replacement, despite the lengthy DAB incubation. Control studies for this extended staining have been described previously (Wood and Newman, 1993a). Sections were mounted onto gel-subbed slides, dehydrated in alcohols and xylenes, and coverslipped with Permount.

\section{Intracellular Localization of Androgen Receptor Immunoreactivity}

To determine the intracellular localization of androgen receptors in normal male and female hamsters, androgen receptor immunoreactivity was examined in gonad-intact males $(n=3)$ and normal cycling females. Estrous cycles were monitored daily according to the methods of Orsini (1961), and all females displayed at least two consecutive 4-day cycles. Females were perfused on day 4 (high endog-

Figure 1 Photomicrographs of androgen receptor immunoreactivity from gonadectomized male (left) and female (right) hamsters in the ventral lateral septum (LSv), posteromedial bed nucleus of the stria terminalis (BNSTpm), and medial preoptic nucleus (MPN). The box represents the area used for optical density measurements (see text for details). III = third ventricle; oc $=$ optic chiasm. Scale bar $=100 \mu \mathrm{m}$. 

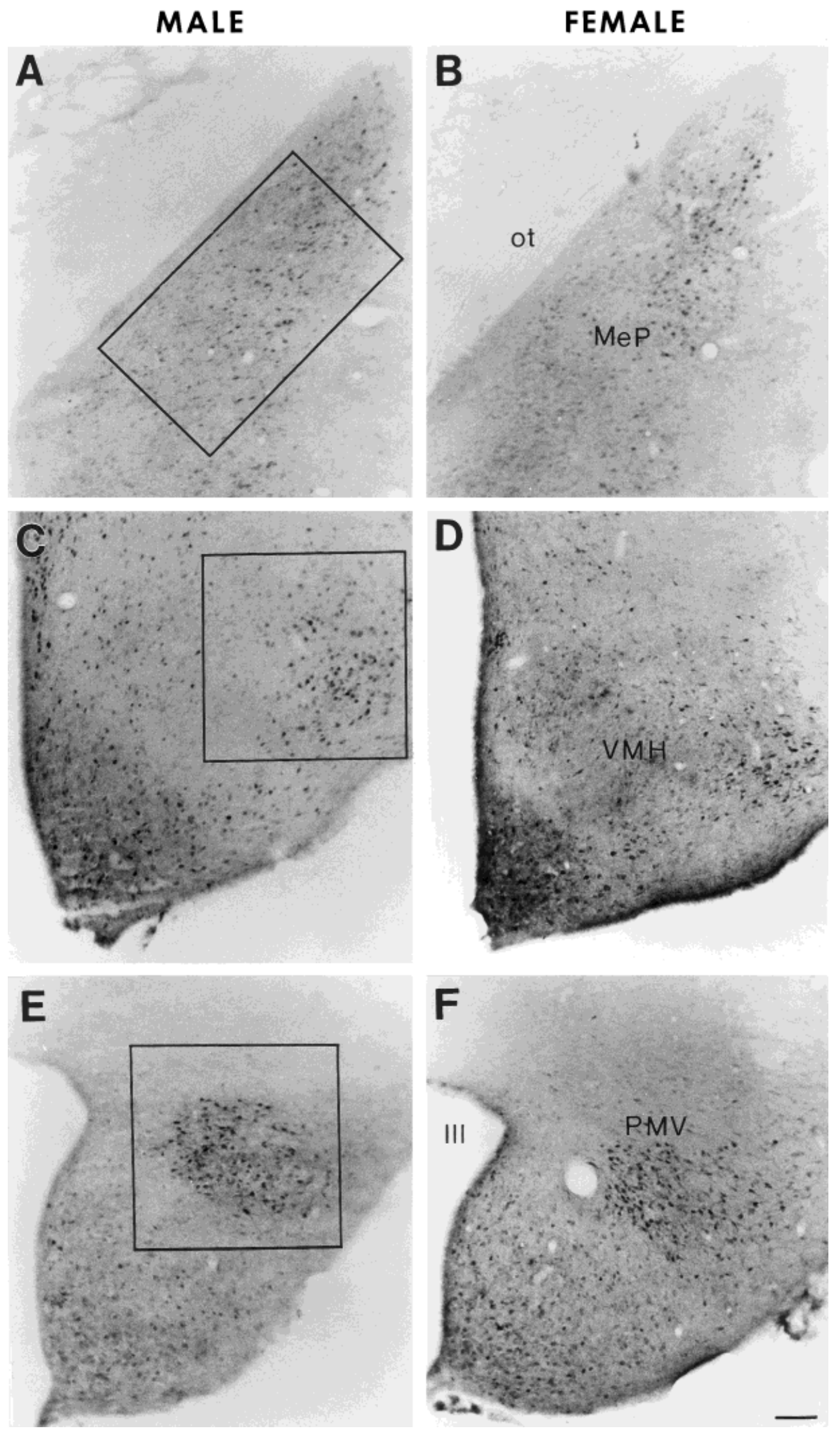
enous estrogen, $n=3$ ) or day 1 (low endogenous estrogen, $n=3$ ) of the estrous cycle.

To understand the hormonal control of androgen receptor partitioning in males and females, the effects of gonadectomy and steroid replacement on the intracellular localization of androgen receptors were determined. Males were castrated via a midline scrotal incision under sodium pentobarbital anesthesia $(65 \mathrm{mg} / \mathrm{kg})$; females were ovariectomized via bilateral flank incisions. Steroids were replaced chronically by means of a Silastic capsule (inner diameter, $1.98 \mathrm{~mm}$; outer diameter, $3.18 \mathrm{~mm}$; Dow Corning, MI) inserted subcutaneously along the dorsal midline immediately after gonadectomy. All hamsters were perfused 2 weeks later. Capsules were packed with $5 \mathrm{~mm}$ of dihydrotestosterone (DHT), a nonaromatizable androgen $(n=3$ males and 3 females), or $4 \mathrm{~mm}$ of estradiol-17 $\beta$ ( $n=3$ each), according to Ellis and Turek (1980). Before implantation, capsules were cleaned in alcohol and preincubated in water overnight to prevent a peak in postimplantation steroid release (Karsch et al., 1973). These steroid implants provide physiologic steroid feedback to the neuroendocrine system sufficient for suppression of gonadotropins under short-day photoperiod (Ellis and Turek, 1980).

\section{Distribution and Staining Intensity of Androgen Receptor-Containing Neurons}

To determine whether a sex difference exists in the number or staining intensity of androgen receptor-containing neurons, androgen receptor immunoreactivity was evaluated by optical density measurements in six brain regions from gonadectomized males and females $(n=6$ each). Males and females were compared 2 weeks after gonadectomy to equalize the endogenous steroid milieu, and sections from males and females were stained at the same time to minimize variations in staining intensity. Brain regions rich in androgen receptors were studied, including the ventral lateral septum (LSv), posteromedial subdivision of the bed nucleus of the stria terminalis (BNSTpm), medial preoptic nucleus (MPN), posterior subdivision of the medial amygdaloid nucleus (MeP), ventral premammillary nucleus (PMV), and lateral subdivision of the ventromedial nucleus of the hypothalamus (VMH). Specific regions examined are depicted by the black boxes in Figures 1 and 2 .

Sections were carefully selected and viewed under bright-field illumination with a Zeiss Axioplan microscope. The microscope was adjusted for Kohler illumination on the $\times 10$ objective. Digitized images of selected brain regions $\left(0.22 \mathrm{~mm}^{2}\right)$ were collected onto an IBM 486 computer using a Hitachi color video camera and evaluated using the Image-1 software package (Universal Imaging Corp, West Chester, PA). Prior to image acquisition, the camera gain and black levels were adjusted so that the gray level of all pixels was between 0 and 255. Black (no illumination) and white (no specimen) reference images were also collected. The same illumination and analog settings were used during acquisition and analysis of all images. Gray-level images acquired from the video camera were converted to optical density (OD) according to the following formula: OD $=-\log (T)$, where $T$, the fractional transmittance, represents (image gray level-black reference image)/(white reference image-black reference image) (McNamara, 1995). The resulting image was thresholded to eliminate background staining. For each animal, the threshold was the average minimum gray level above background staining determined from three measurements of an androgen receptor-negative region of the parietal cortex. The average integrated optical density (IOD) per cell of the thresholded image, in which IOD represents the sum of the all pixel ODs for each cell, and the number of cells within a $0.22 \mathrm{~mm}^{2}$ region were recorded.

To validate this approach, we compared the number of cells in LSv identified by the Image-1 system with those counted by an observer blind to the experimental group, using a microscope equipped with a drawing tube (Fig. 3). Sections from six gonad-intact males, six castrated males, and six ovariectomized females were evaluated. Cell counts using these two methods were not significantly different $(p<.05)$. Moreover, there was a significant correlation between number of cells recorded by the Image- 1 system and by the blind observer (slope $=0.92$, $\left.R^{2}=0.74, p<.05\right)$.

For comparisons between males and females in LSv, BNSTpm, MPN, VMH, MeP and PMV, one section per animal through each region was analyzed bilaterally using the Image- 1 system from six castrated male and six ovariectomized female hamsters. The bilateral measurements for each region in each animal were averaged. Matching sections were selected for analysis from each animal after careful evaluation of the staining throughout the region of interest to ensure that the measured values for androgen receptor immunoreactivity were representative of staining in that region. Differences in the number of immunostained cells and the intensity of staining (IOD/cell) between males and females for each region were evaluated using analysis of variance with repeated measures. The Scheffé $F$ test was used for post-hoc comparisons.

Figure 2 Photomicrographs of androgen receptor immunoreactivity from gonadectomized male (left) and female (right) hamsters in the posterior subdivision of the medial amygdaloid nucleus $(\mathrm{MeP})$, ventromedial nucleus of the hypothalamus $(\mathrm{VMH})$, and ventral premammillary nucleus (PMV). The box represents the area used for optical density measurements (see text for details). III $=$ third ventricle; ot $=$ optic tract. Scale bar $=100 \mu \mathrm{m}$. 


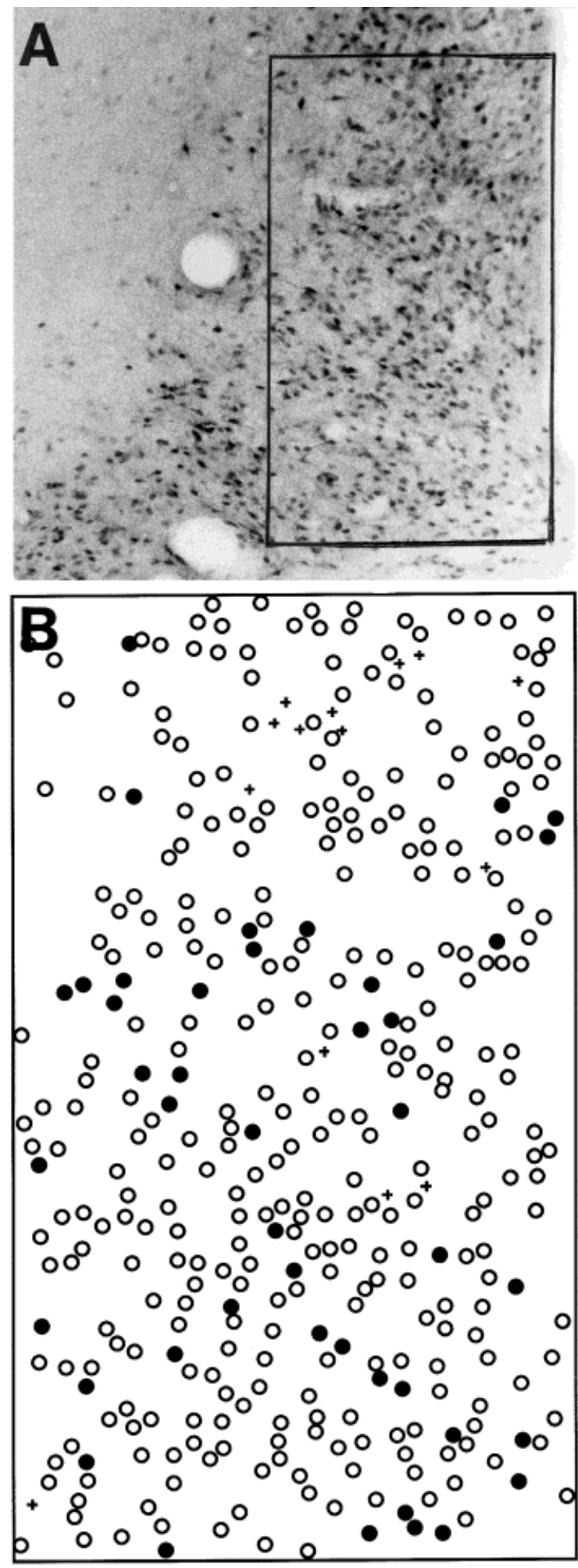

351 cells counted on camera lucida $(0, \bullet)$ 317 cells counted on Image-1 $(0,+)$

Figure 3 (A) Photomicrograph of androgen receptor immunostaining in the lateral septum from a gonad-intact male hamster. The rectangle indicates the area of cell counts. (B)

\section{RESULTS}

Figure 4 compares androgen receptor-containing neurons in PMV of gonadectomized [Fig. 4(A,B)] and gonad-intact male and female hamsters [Fig. 4(C-E)]. As shown previously (Menard and Harlan, 1993; Wood and Newman, 1993a,b; Clancy et al., 1994), androgen receptor immunostaining in the gonad-intact male was visible exclusively within the neuronal cell nucleus [Fig. 4(C)], in contrast to immunostaining of cellular processes in gonadectomized males [Fig. 4(A)]. Immunostaining of the cell nucleus was more intense than that in the cytoplasm. Interestingly, the intensity of cytoplasmic immunostaining varied among neurons within any single brain region; labeled processes were not visible in all androgen receptorcontaining neurons. Similar observations have been reported for cytoplasmic estrogen receptors (Blaustein and Turcotte, 1989). In ovariectomized females, androgen receptor immunoreactivity was visible in both the nuclear and cytoplasmic compartments [Fig. 4(B)]. However, in ovary-intact females on days 4 [high endogenous estrogen; Fig. 4(D)] and 1 [low endogenous estrogen; Fig. 4(E)] of the 4-day estrous cycle, androgen receptors were evident only within the nucleus, regardless of endogenous estrogen secretion. As in males exposed to very low concentrations of androgens (Wood and Newman, 1995), this nuclear immunoreactivity from gonad-intact females developed slowly in DAB and was less robust, regardless of the day of the cycle, than that of gonad-intact males.

To determine the hormonal control of androgen receptor partitioning, Figure 5 illustrates androgen receptor immunoreactivity in LSv of gonadectomized males and females in the presence and absence of exogenous gonadal steroids. In contrast to the cytoplasmic androgen receptor staining in brains of gonadectomized males and females [Fig. 5(A,B)], exposure to low physiologic concentrations of dihydrotestosterone maintained androgen receptor immunoreactivity exclusively within the neuronal cell nucleus [Fig. 5(C,D)]. Estradiol at physiologic concentrations was not effective in this regard [Fig. $5(\mathrm{E}, \mathrm{F})]$. In the estradiol-treated males and females, staining of neuronal processes was visible (see arrows), although cytoplasmic immunoreactivity was less apparent than in untreated, gonadectomized male and female hamsters [Fig. 5(A,B)].

Immunostained neurons identified by a trained observer (circles) or by the Image-1 system (open circles, crosses). 
Although the hormonal regulation of intracellular androgen receptor immunoreactivity was similar in males and females, the anatomical distribution of androgen receptors in the limbic system was sexually dimorphic. For both males and females, androgen receptors were most abundant in areas reported previously using autoradiography and immunocytochemistry (Wood et al., 1992, Wood and Newman, 1993b). Figures 1 and 2 present photomicrographs of androgen receptor-immunoreactive neurons from representative gonadectomized males and females in each of six brain regions examined using the Image-1 system. The number of immunostained cells and the IOD/cell from males and females in each region is compared in Figure 6. The greatest number of androgen receptorcontaining neurons was found in $\operatorname{LSv}$ (437.8 \pm 51 cells $/ 0.22 \mathrm{~mm}^{2}$ for males), while the neurons in PMV had the highest IOD/cell (5.64 \pm 0.9 units). In PMV, the lateral subdivision of $\mathrm{VMH}$, and MeP (Fig. 2), androgen receptor immunoreactivity was not sexually dimorphic in terms of the number or staining intensity of androgen-responsive neurons (Fig. 6) $(p<.05)$. However, in LSv, BNSTpm, and MPN (Fig. 1), there were fewer androgen-responsive neurons in female hamster brain identified by Image-1, compared with the brains of males (Fig. 6) $(p<.05)$. The IOD/cell in males and females was not significantly different for LSv and MPN. In BNSTpm, IOD/cell for androgen receptor immunostaining was significantly less in females $(1.28 \pm 0.3$ units vs. $2.21 \pm 0.2$ units for males; $p<.05)$.

\section{DISCUSSION}

This study reports the distribution of androgen receptors in limbic neurons of the female hamster brain and the presence of a limited population of receptors in the neuronal cell cytoplasm in the absence of steroids. The intracellular partitioning of the androgen receptor between the cytoplasm and nucleus in the female in response to DHT and estradiol is similar to that of the male (Wood and Newman, 1993b), presumably reflecting ligand binding (Menard and Harlan, 1993; Wood and Newman, 1993a; Freeman et al., 1995; Kashon et al., 1995). Accordingly, the nuclear localization of androgen receptor immunostaining in the normally cycling female suggests that androgen receptors in the female brain bind ligand and have the potential to influence neuronal activity. However, males and females differ in the distribution of androgen receptor-immunoreactive neurons. The low numbers of androgen receptor-positive cells in LSv, MPN, and BNSTpm of females may contribute to sex differences in the behavioral and neuroendocrine responses to androgens (DeBold and Clemens, 1978; Yellon et al., 1989).

The presence of receptor within the cell cytoplasm in the absence of ligand has been demonstrated immunohistochemically for all major classes of steroid hormones [estrogen (Blaustein and Turcotte, 1989; Fox et al., 1991; Blaustein, 1992; Blaustein et al., 1992); progesterone (Blaustein et al., 1992); glucocorticoid (Ahima and Harlan, 1991); androgen (Wood and Newman, 1993a; Freeman et al., 1995; Kashon et al., 1995)]. Such observations are nonetheless compatible with the predominantly nuclear receptor localization proposed by King and Greene (1984) and Welshons et al. (1984), because cytoplasmic steroid receptors are a small fraction of those present in the cell nucleus. The intracellular partitioning of androgen receptor immunoreactivity between the cell cytoplasm and nucleus can be used as an index of receptor binding in the brain. Stimuli that eliminate cytoplasmic staining, such as exogenous androgen, are presumed to cause nuclear translocation of the hormonereceptor complex (Freeman et al., 1995), which then acts on DNA (Carson-Jurica et al., 1990). Viewed in this context, a treatment that prevents cytoplasmic immunoreactivity has the potential to influence activity of androgen receptor-containing neurons.

Although alterations in cytoplasmic immunostaining are one effect of steroid manipulations on androgen receptor-immunoreactive neurons, the actions of steroids on androgen receptors are not limited to intracellular compartmentalization. Exposure to androgens also increases nuclear staining intensity (Menard and Harlan, 1993; Wood and Newman, 1993a; Zhou et al., 1994; Freeman et al., 1995; Kashon et al., 1995). One model of androgen receptor autoregulation (Freeman et al., 1995; Kashon et al., 1995) is that androgens initially concentrate existing receptors in the cell nucleus, and subsequently stimulate synthesis of additional receptors (Kerr et al., 1995; Simerly, 1993). Certainly, the duration of steroid treatment employed in the present study ( 2 weeks) is sufficient for both mechanisms to occur.

In the present study, we used the presence or absence of cytoplasmic androgen receptor immunoreactivity to make inferences about androgen receptor binding in response to hormonal challenge in the brains of male and female hamsters. The partitioning of androgen receptor immunoreactivity in males and females in response to exogenous steroids is similar. These findings suggest that the androgen receptor in the female is capable of ligand binding, a conclusion supported by biochemical studies using receptor binding assays (Barley et al., 1975; Attardi et al., 1976; 


\section{MALE}
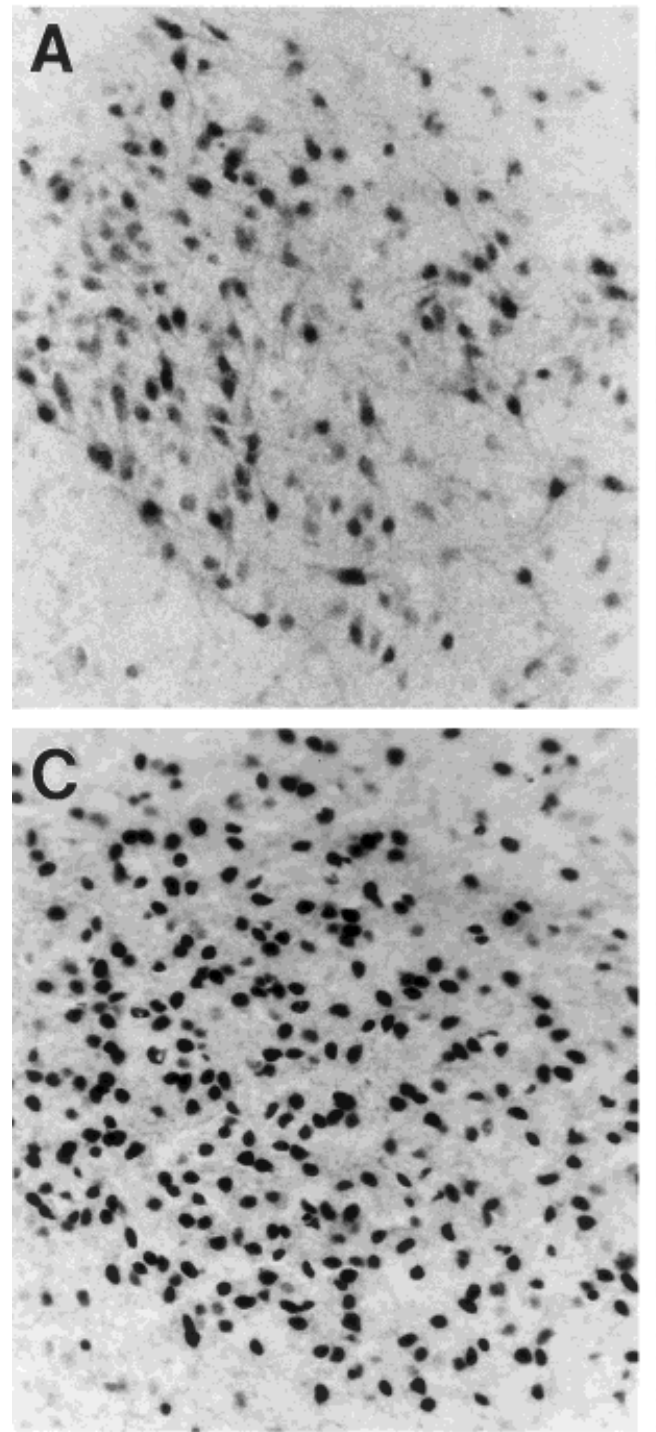

FEMALE
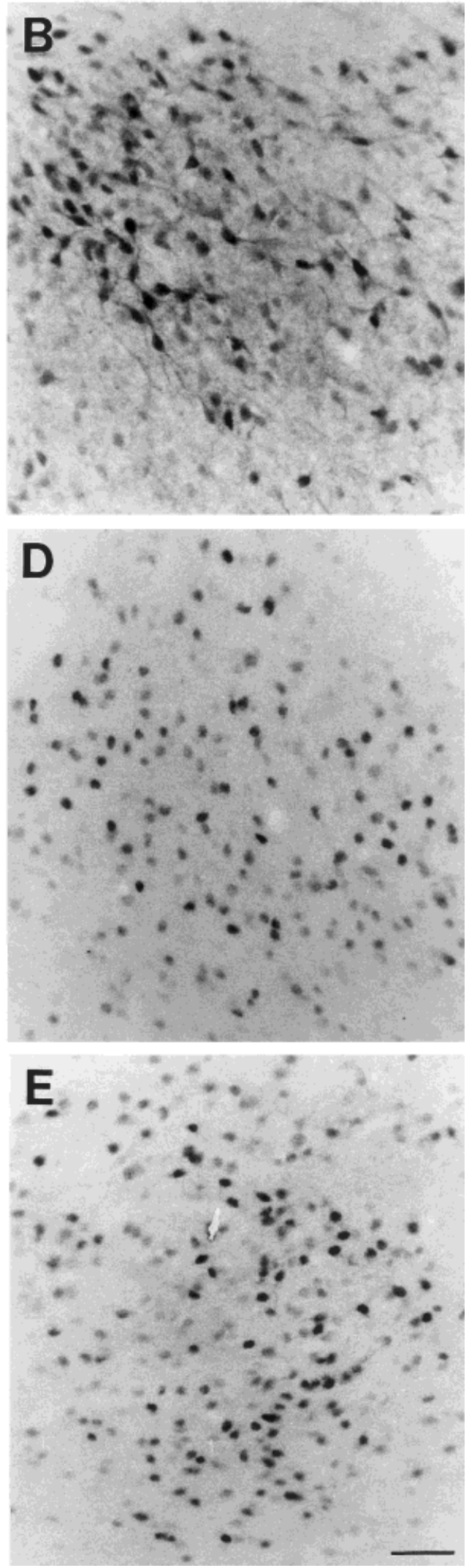
Handa et al., 1986; Ahdieh and Feder, 1988; Roselli et al., 1989; Roselli, 1991; Chen and Tu, 1992), and that under physiologic conditions only androgen is an adequate hormonal stimulus for androgen receptor binding. The effects of exogenous steroids on androgen receptor immunoreactivity in gonadectomized males and females provide a framework for understanding the intracellular localization of androgen receptors in the gonad-intact male and female. We interpret the lack of cytoplasmic immunostaining in gonad-intact females to reflect the presence of very low concentrations of ovarian androgens which act on the female brain. Several pieces of evidence support this conclusion. The present study indicates that estrogen at physiologic concentrations cannot maintain nuclear androgen receptor immunoreactivity. The faint nuclear immunoreactivity of the gonad-intact female is similar to the appearance of androgen receptor-containing neurons in the photosuppressed male (Wood and Newman, 1993a), in which androgen production by the testes is at a nadir (Bartke, 1985). Endogenous androgens are detectable at low levels in circulation throughout the estrous cycle in the female rat (Handa et al., 1986), and it appears that the ovary, rather than the adrenal, is the principle source of such androgens because androgen receptor immunoreactivity develops in the cytoplasm following ovariectomy alone. We do not know whether the androgen receptors detected in the cytoplasm of gonadectomized hamsters are present in biologically meaningful quantities. However, faint nuclear androgen receptor immunoreactivity, such as that seen in gonad-intact females and short-day males, can have physiologic significance. In particular, short-day males are exquisitely sensitive to steroid negative feedback, and the low levels of testosterone in circulation are sufficient to inhibit the reproductive neuroendocrine system (Bartke, 1985). Thus, endogenous ovarian androgens appear to act on androgen receptor-containing neurons in the brains of female hamsters, and have the potential to influence neuronal activity.

The normal function of endogenous androgens in the brain of the cycling female has not been resolved. It has been suggested that androgens per se are important to the preovulatory surge of FSH in females (Gay and Tomacari, 1973). Certainly, exogenous androgens can elicit behavioral and neuroendocrine responses in females (DeBold and Clemens, 1978; Yel- lon et al., 1989). However, males and females differ quantitatively in their response to androgens. For instance, sensitivity to feedback suppression of FSH secretion by DHT is markedly reduced in female hamsters (Yellons et al., 1989). Likewise, exogenous androgens are less effective in stimulating male copulatory behavior in female hamsters (DeBold and Clemens, 1978). Since androgen receptors appear to be functional in the female, these effects may be due to sex differences in the distribution of androgen receptors in males and females. In the present study, castrated males possessed significantly more androgen receptor-immunoreactive neurons than ovariectomized females in specific brain regions. This sex difference was not limited to males and females in the absence of steroids, but was also evident in hamsters treated with DHT (see Fig. 5). Such observations are not without precedent. It has been reported that males have higher levels of androgen receptor than females in MPN using receptor binding assay [hamster (Chen and Tu, 1992); rat (Roselli, 1991); guinea pig (Ahdieh and Feder, 1988); zebra finch anterior telencephalon (Siegel et al., 1986)], autoradiography (Lisciotto and Morrell, 1994; Schleicher et al., 1986), or in situ hybridization (Simerly et al., 1990; McAbee and DonCarlos, 1998). A similar sex difference has been described for the BNSTpm (Schleicher et al., 1986; Roselli, 1991; McAbee and DonCarlos, 1998). These sex differences develop during the early postnatal period in the rat (McAbee and DonCarlos, 1998). In females, the lower levels of androgen receptor immunoreactivity in MPN and BNSTpm, brain regions implicated in the control of male copulatory behavior (Powers et al., 1987) and tonic gonadotropin secretion (Simerly, 1995), could contribute to the reduced effectiveness of exogenous androgen to stimulate maletypical reproductive responses in females (DeBold and Clemens, 1978; Yellon et al., 1989). The functional significance of sex differences in androgen receptor staining in LSv is less clear. However, it is noteworthy that androgen receptor staining is equivalent in males and females in other brain regions. This includes $\mathrm{Me}$ and PMV, which are involved in male sexual behavior. The presence of androgen receptors in VMH, which is associated with female sex behavior and stimulation of phasic gonadotropin release (Pfaff et al., 1994), is consistent with a functional role

Figure 4 Photomicrographs of androgen receptor immunoreactivity in the ventral premammillary nucleus (PMV) from representative male (left) and female (right) hamsters in the absence (A,B) and presence of the gonads (C-E). Females were sacrificed on day 4 (D) or 1 (E) of the estrous cycle. Scale bar $=50 \mu \mathrm{m}$. 


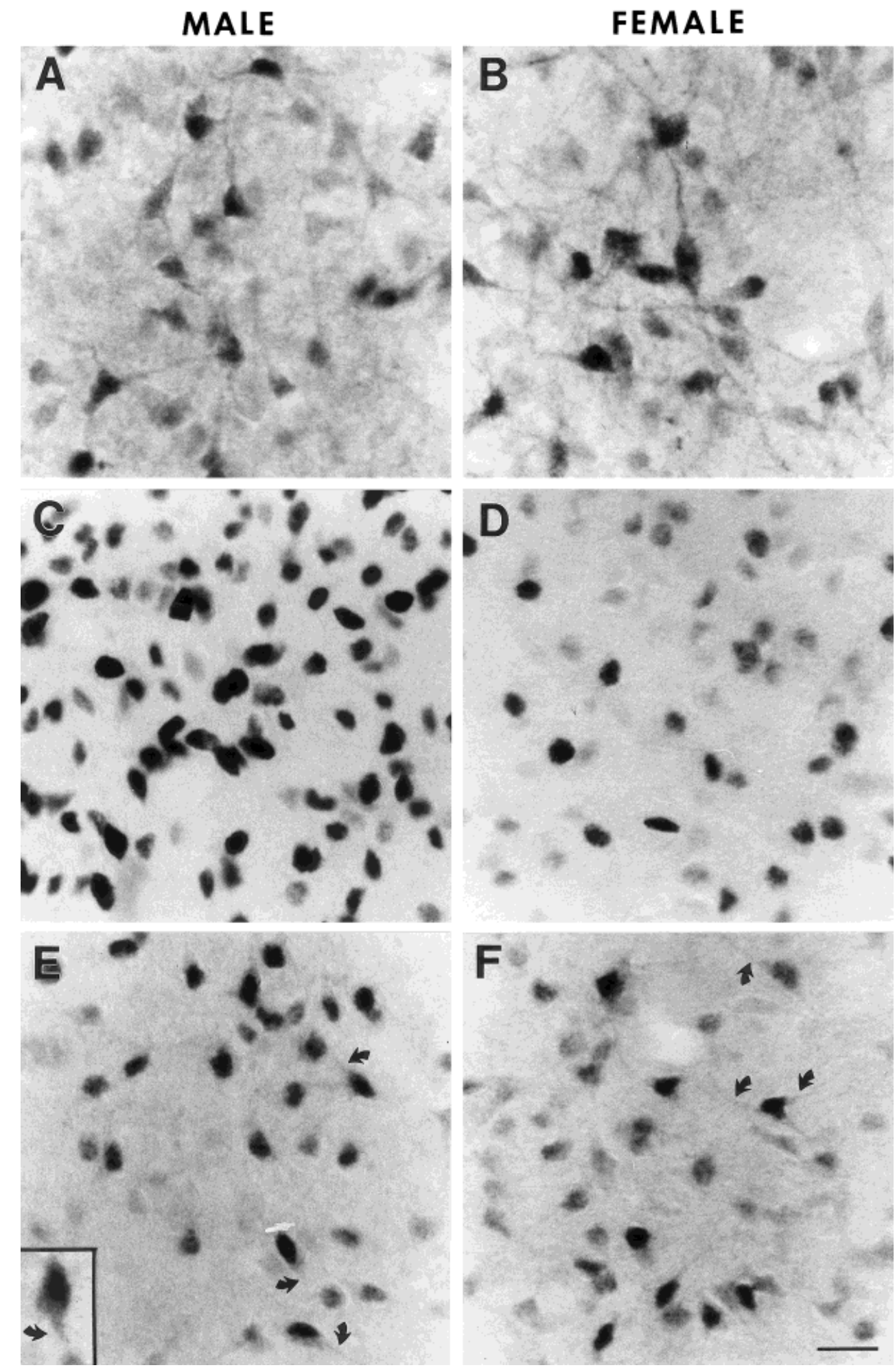

Figure 5 Photomicrographs of androgen receptor immunoreactivity in the ventral lateral septum (LSv) from representative male (left) and female (right) hamsters gonadectomized for 2 weeks $(\mathrm{A}, \mathrm{B})$, and from gonadectomized males and females replaced with dihydrotestosterone (C,D) or estradiol (E,F) at physiologic levels. (Inset) High-power view of cytoplasmic staining in estradioltreated male. Scale bar $=20 \mu \mathrm{m}$. 

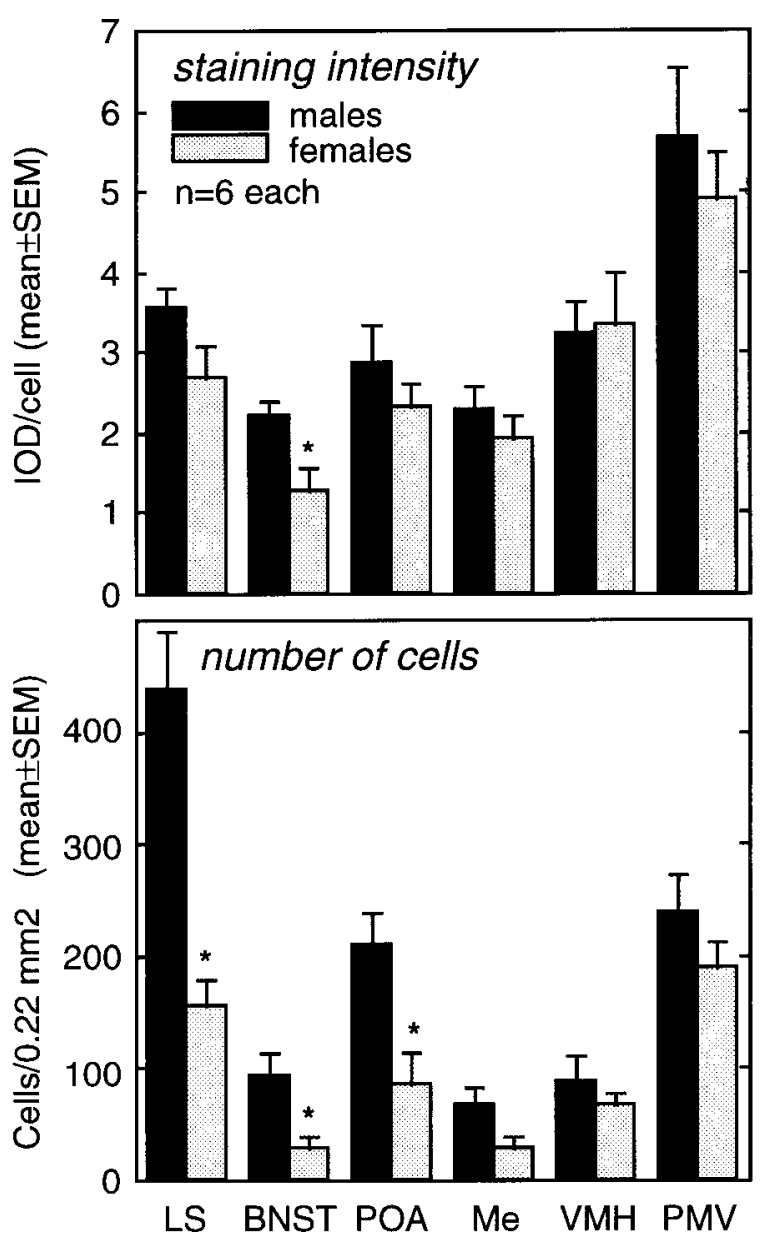

Figure 6 Androgen receptor immunoreactivity from gonadectomized male and female hamsters $(n=6$ each) in six brain regions that contain large numbers of androgen receptor-containing neurons. (Top) Integrated optical density per cell (mean \pm S.E.M.) from a $0.22-\mathrm{mm}^{2}$ area within each brain region. (Bottom) Number of cells. Asterisks indicate significant $(p<.05)$ differences between males and females. BNSTpm = bed nucleus of the stria terminalis; Lsv $=$ ventral lateral septum; $\mathrm{MeP}=$ posterior medial amygdaloid nucleus; MPN = medial preoptic nucleus; PMV = ventral premammillary nucleus; $\mathrm{VMH}=$ ventromedial nucleus of the hypothalamus.

for endogenous androgens in the reproductive response of the normal female.

The authors thank Dr. Gail S. Prins of the University of Illinois-Chicago for the androgen receptor antiserum; Lorita Dudus and R. Kaye Brabec of the Reproductive Sciences Program Morphology Core Facility (P30-HD18258) for assistance with tissue processing; and Dr. Steven E. Asmus, Dr. Lique M. Coolen, and Dr. Sara KollackWalker for their critical evaluation of the manuscript. This work was supported by research and training grants from the NIH (NS-20629 and HD-07514).

\section{REFERENCES}

Ahdieh HB, Feder HH. 1988. Sex differences in nuclear androgen receptors in guinea pig brain and the effects of an $\alpha 2$ noradrenergic blocker on androgen receptors. Brain Res 456:275-279.

Ahima RS, Harlan RE. 1991. Differential corticosteroid regulation of Type II glucocorticoid receptor-like immunoreactivity in the rat central nervous system: topography and implications. Endocrinology 129:226-236.

Attardi B, Geller LN, Ohno S. 1976. Androgen and estrogen receptors in brain cytosol from male, female, and testicular feminized mice. Endocrinology 98:864-874.

Barley J, Ginsburg M, Greenstein BD, MacLusky NJ, Thomas PJ. 1975. An androgen receptor in rat brain and pituitary. Brain Res 100:383-393.

Bartke A. 1985. Male hamster reproductive endocrinology. In: Siegel HI, editor. The hamster: reproduction and behavior. New York: Plenum Press. p 73-98.

Blaustein JD. 1992. Cytoplasmic estrogen receptors in rat brain: immunocytochemical evidence using three antibodies with distinct epitopes. Endocrinology 131:13361342.

Blaustein JD, Lehman MN, Turcotte JC, Greene G. 1992. Estrogen receptors in dendrites and axon terminals in the guinea pig hypothalamus. Endocrinology 131:281-290.

Blaustein JD, Turcotte JC. 1989. Estrogen receptor-immunostaining of neuronal cytoplasmic processes as well as cell nuclei in guinea pig brain. Brain Res 495:75-82.

Carson-Jurica MA, Schrader WT, O’Malley BW. 1990. Steroid receptor family: structure and functions. Endocr Rev 11:201-220.

Chen TJ, Tu WW. 1992. Sex differences in estrogen and androgen receptors in hamster brain. Life Sci 50:16391647.

Clancy AN, Whitman C, Michael RP, Albers HE. 1994. Distribution of androgen receptor-like immunoreactivity in the brains of intact and castrated male hamsters. Brain Res Bull 33:325-332.

DeBold JF, Clemens LG. 1978. Aromatization and the induction of male sexual behavior in male, female, and androgenized female hamsters. Horm Behav 11:401413.

Ellis GB, Turek FW. 1980. Photoperiod-induced change in responsiveness of the hypothalamic-pituitary axis to exogenous $5 \alpha$-dihydrotestosterone and $17 \beta$-estradiol in castrated male hamsters. Neuroendocrinology 31:205-209.

Fox CA, Ross LR, Handa RJ, Jacobsen CD. 1991. Localization of cells containing estrogen receptor-like immunoreactivity in the Brazilian opossum brain. Brain Res 546:96-105.

Freeman LM, Padgett BA, Prins GS, Breedlove SM. 1995. Distribution of androgen receptor immunoreactivity in the spinal cord of wild-type, androgen-insensitive and gonadectomized male rats. J Neurobiol 27:51-59.

Gay, VL, Tomacari RL. 1973. Follicle-stimulating hormone secretion in the female rat: cyclic release is dependent on circulating androgen. Science 184:75-77. 
Gorski J, Toft D, Shyamala G, Smith D, Notides A. 1968. Hormone receptors: studies on the interaction of estrogens with the uterus. Recent Prog Horm Res 24:45-80.

Gustafsson JA, Pousette A, Svensson E. 1976. Sex-specific occurrence of androgen receptors in rat brain. J Biol Chem 251:4047-4054.

Handa RJ, Reid DL, Resko JA. Androgen receptors in brain and pituitary of female rats: cyclic changes and comparisons with the male. Biol Reprod 34:293-303.

Karsch FJ, Dierschke DJ, Weick RF, Yamaji T, Hotchkiss J, Knobil E. 1973. Positive and negative feedback control by estrogen of luteinizing hormone secretion in the rhesus monkey. Endocrinology 92:799-804.

Kashon ML, Hayes MJ, Shek PP, Sisk CL. 1995. Regulation of brain androgen receptor immunoreactivity by androgen in prepubertal male ferrets. Biol. Reprod 52: 1198-1205.

Kerr JE, Allore RJ, Beck SG, Handa RJ. 1995. Distribution and hormonal regulation of androgen receptor (AR) and AR messenger ribonucleic acid in the rat hippocampus. Endocrinology 136:3213-3221.

King WJ, Greene GL. 1984. Monoclonal antibodies localize oestrogen receptor in the nuclei of target cells. Nature 307:745-749.

Lisciotto CA, Morrell JI. 1994. Sex differences in the distribution and projections of testosterone target neurons in the medial preoptic area and the bed nucleus of the stria terminalis of rats. Horm Behav 28:492-502.

McAbee MD, DonCarlos LL. 1998. Ontogeny of regionspecific sex differences in androgen receptor messenger ribonucleic acid expression in the rat forebrain. Endocrinology 139:1738-1745.

McNamara G. 1995. MVPMATH Program for Image-1/AT. West Chester, PA: Universal Imaging Corporation.

Menard CS, Harlan RE. 1993. Up-regulation of androgen receptor immunoreactivity in the rat brain by androgenicanabolic steroids. Brain Res 622:226-236.

Orsini MW. 1961. The external vaginal phenomena characterizing the stages of the estrous cycle, pregnancy, pseudopregnancy, lactation, and the anestrous hamster $\mathrm{Me}$ socricetus auratus Waterhouse. Proc Anim Care Panel 11:193-206.

Pfaff DW, Schwartz-Giblin S, McCarthy M, Kow L-M. 1994. Cellular mechanisms of female reproductive behaviors. In: Knobil E, Neill JD, editors. The physiology of reproduction. Vol. 2. New York: Raven Press. p 107220.

Powers JB, Bergondy ML, Matochik JA. 1985. Male hamster sociosexual behaviors: effects of testosterone and its metabolites. Physiol. Behav. 35:607-616.

Powers, J.B., Newman, S.W., and Bergondy, M.L. (1987). MPOA and BNST lesions in male Syrian hamsters: differential effects on copulatory and chemoinvestigatory behaviors. Behav Brain Res 23:181-195.

Prins GS, Birch L, Greene GL. 1991. Androgen receptor localization in different cell types of the adult rat prostate. Endocrinology 129:3187-3199.

Roselli CE. 1991. Sex differences in androgen receptors and aromatase activity in microdissected regions of the rat brain. Endocrinology 128:1310-1316.

Roselli CE, Handa RJ, Resko JA. 1989. Quantitative distribution of nuclear androgen receptors in microdissected areas of the rat brain. Neuroendocrinology 49:449-453.

Schleicher G, Stumpf WE, Drews U, Sar M. 1986. Autoradiographic studies with $3 \mathrm{H}$ dihydrotestosterone in the brain of sex reversed mice, heterozygous for androgen insensitive testicular feminization (Tfm). Histochemistry 84:23-29.

Siegel LI, Akutagawa E, Fox TO, Konishi M, Politch JA. 1986. Androgen and estrogen receptors in adult zebra finch brain. J Neurosci Res 16:617-628.

Simerly RB. 1993. Distribution and regulation of steroid hormone receptor gene expression in the central nervous system. In: Seil FJ, editor. Advances in neurology. Vol. 59. New York: Raven Press. p 473-484.

Simerly RB. 1995. Hormonal regulation of limbic and hypothalamic pathways. In: Micevych PE, Hammer RP Jr, editors. Neurobiological effects of sex steroid hormones. Cambridge: Cambridge University Press. p 85-114.

Simerly RB, Chang C, Muramatsu M, Swanson LW. 1990. Distribution of androgen and estrogen receptor mRNAcontaining cells in the rat brain: an in situ hybridization study. J Comp Neurol 294:76-95.

Welshons WV, Lieberman ME, Gorski J. 1984. Nuclear localization of unoccupied oestrogen receptors. Nature 307:747-749.

Wood RI, Brabec RK, Swann JM, Newman SW. 1992. Androgen and estrogen receptor-containing neurons in chemosensory pathways of the male Syrian hamster brain. Brain Res 596:89-98.

Wood RI, Newman SW. 1995. Hormonal influence on neurons of the mating behavior pathway in male hamsters. In: Micevych PE, Hammer RP Jr, editors. Neurobiological effects of sex steroid hormones. Cambridge: Cambridge University Press. p 3-39.

Wood RI, Newman SW. 1993a. Intracellular partitioning of androgen receptor immunoreactivity in the brain of the male Syrian hamster: effects of castration and steroid replacement. J Neurobiol 24:925-938.

Wood RI, Newman SW. 1993b. Mating activates androgen receptor-containing neurons in chemosensory pathways of the male Syrian hamster brain. Brain Res 614:65-77.

Yellon SM, Hutchison JS, Goldman BD. 1989. Sexual differentiation of the steroid feedback mechanism regulating follicle-stimulating hormone secretion in the Syrian hamster. Biol Reprod 40:7-14.

Zhou L, Blaustein JD, De Vries GJ. 1994. Distribution of androgen receptor immunoreactivity in vasopressin- and oxytocin-immunoreactive neurons in the male rat brain. Endocrinology 134:2622-2627. 